\title{
PENGARUH PENGGUNAAN KOLOM PASIR, LAYER PASIR, DAN TERUCUK BAMBU PADA TANAH LEMPUNG JENUH AIR TERHADAP PENURUNAN TANAH LEMPUNG MENGGUNAKAN UJI LABORATORIUM
}

\author{
Dian Eksana Wibowo', Satriarda Dirgantara S. ${ }^{2}$, Ridwan Kurniawan ${ }^{3}$ \\ 1,2,3 Jurusan Pendidikan Teknik Sipil dan Perencanaan FT UNY \\ Email: dian.eksana@uny.ac.id
}

\begin{abstract}
ABSTRAK
Penelitian ini bertujuan untuk mengetahui klasifikasi jenis tanah, properti tanah pengujian dan pengaruh penggunaan metode penambahan variasi tanah lempung jenuh air dengan menggunakan pasir dan cerucuk bambu, terhadap penurunan tanah lempung, kadar air, dan analisis T90. Penelitian eksperimen dengan menggunakan model boks baja, berukuran $100 \mathrm{~cm} \times 100 \mathrm{~cm} \times 40 \mathrm{~cm}$ sebagai media penempatan tanah lempung. Hasil penelitian ini yaitu: (1) Jenis tanah termasuk $\mathrm{CH}$ (Clay High Plasticity) menurut klasifikasi USCS dan kelompok 4-7-6(40) menurut klasifikasi AASTHO. (2) Properti tanah adalah $\mathrm{G}=2,63, \mathrm{LL}=74,71 \%, \mathrm{PL}=29,76 \%, \mathrm{IP}=44,95 \%, \quad \mathrm{SL}=19,06 \%, \mathrm{C}=0,75 \mathrm{~kg} / \mathrm{cm}^{2}$, $\mathrm{OMC}=39,2 \%$. (3) Penambahan TPV sangat efektif memperkecil penurunan. Pada pemberian tekanan $0,0125 \mathrm{~kg} / \mathrm{cm}^{2}$, $0,025 \mathrm{~kg} / \mathrm{cm}^{2}, 0,05 \mathrm{~kg} / \mathrm{cm}^{2}$, dan $0,01 \mathrm{~kg} / \mathrm{cm}^{2}$ memperkecil penurunan, berturut-turut: 75,93\%; 56,32\%; 59,44\% dan $42,32 \%$. Pada kedalaman $-10 \mathrm{~cm}$ penggunaan TPH paling efektif mengurangi kadar air tanah lempung yaitu sebesar $53,30 \%$, berarti mengurangi kadar air sebesar 3,62\% dari kondisi tanah asli (TTD). Pada kedalaman $20 \mathrm{~cm}$, penggunaan TCB paling efektif mengurangi kadar air sebesar 3,55\% dari kadar air tanah lempung asli (TTD). Penggunaan CTPVH pada beban $0,1 \mathrm{~kg} / \mathrm{cm}^{2}$ paling efektif dalam proses konsolidasi yaitu sebesar $94,10 \%$ dari tanah asli (TTD) dimana mempunyai nilai sebesar nilai t90 untuk CTPVH yaitu sebesar 15,21 menit.
\end{abstract}

Kata Kunci: air, perkuatan, tanah lempung, T90

\begin{abstract}
This study aims to determine the classification of soil types, soil properties tested and the effect of using the method of adding variations in the water-saturated clay, using sand and bamboo piles, to clay settlement, moisture content, and T90 analysis. The experimental study used a steel box model, measuring $100 \mathrm{~cm} \times 100 \mathrm{~cm} \times 40 \mathrm{~cm}$ as a medium for clay placement. The results of this study are: (1) Soil types including $\mathrm{CH}$ (Clay High Plasticity) according to USCS classification and groups 4-7-6 (40) according to AASTHO classification. (2) Soil properties is $G=2,63, L L=74,71 \%$, $P L=29,76 \%, I P=44,95 \%, S L=19,06 \%, C=0,75 \mathrm{~kg} / \mathrm{cm}^{2}, O M C=39,2 \%$. (3) Addition of TPV is very effective in reducing the settlement. At a pressure of $0,0125 \mathrm{~kg} / \mathrm{cm}^{2}, 0,025 \mathrm{~kg} / \mathrm{cm}^{2}, 0,05 \mathrm{~kg} / \mathrm{cm}^{2}$, and $0.01 \mathrm{~kg} / \mathrm{cm}^{2}$ minimizing the settlement, respectively: $75,93 \% ; 56,32 \% ; 59,44 \%$ and $42,32 \%$. At depths of $-10 \mathrm{~cm}$ the most effective use of TPH reduces clay soil moisture content by 53,30\%, which means reducing water content by 3,62\% from the original soil conditions (TTD). At a depth of $20 \mathrm{~cm}$, using TCB is most effective at reducing water content by 3,55\% from the original clay soil content (TTD). The use of CTPVH at a load of $0,1 \mathrm{~kg} / \mathrm{cm}^{2}$ is most effective in the consolidation process which is $94.10 \%$ of the original soil (TTD) which has a value of T90 for CTPVH which is 15,21 minutes.
\end{abstract}

Keywors: water, strainthening, clay, T90

\section{PENDAHULUAN}

Hardiyatmo (1999) berpendapat, tanah lempung memiliki sifat permeabilitas rendah, kenaikan air kapiler tinggi, bersifat sangat kohesif, kadar kembang susut yang tinggi, dan proses konsolidasi lambat. Sehingga jenis tanah lempung ini sangat berpengaruh terhadap konstruksi yang ada di atasnya karena dapat retak, amblas maupun terangkat. Hal ini terjadi akibat sifat kembang susut pada tanah lempung.

Istilah "tanah" dalam bidang mekanika tanah dimaksudkan untuk mencangkup semua bahan dari tanah lempung sampai kerakal; jadi semua endapan alam yang bersangkutan dengan Teknik sipil kecuali batuan. Batuan menjadi ilmu tersendiri, yaitu mekanika batuan (Wesley, 2012). 
Menurut Bowles (1986), Tanah lempung mempunyai sifat plastisitas yang tinggi dan kohesif sehingga jika digunakan untuk suatu pekerjaan konstruksi harus diberi perlakuan khusus terlebih dahulu baru bisa digunakan untuk suatu pekerjaan konstruksi.

Kurangnya pengetahuan masyarakat mengenai karakteristik tanah lempung dan cara perkuatan atau perbaikan tanah lempung yang tepat, merupakan salah satu faktor utama masyarakat yang tinggal di daerah tanah lempung sehingga bangunan akan rusak akibat deformasi yang diakibatkan oleh kembang susut tanah lempung. Dimana tidak melakukan perkuatan atau perbaikan terlebih dahulu pada saat proses pelaksanaan pekerjaan konstruksi baik untuk embankment atau timbunan jalan raya atau mendirikan suatu bangunan.

Banyak metode pekerjaan perbaikan atau perkuatan tanah terutama pada tanah lempung salah satunya menggunakan metode penambahan pasir dalam tanah. Menurut Risdianta, (2018) pemakaian pasir pada perbaikan pondasi dangkal dengan metode Preloading dengan kombinasi Prefabricated Vertical Drain (PVD) dan Prefabricated Horizontal Drain (PHD) mengalami kenaikan daya dukung ponasai sebesar $26 \%$ dari sebelum dilakukan perbaikan.

Selain menggunakan pasir untuk memberikan perkuatan pada tanah lempung, ada metode lain untuk memperkuat tanah dengan kemudahan mendapatkan bahan dan dengan harga yang relative murah juga yaitu dengan menggunakan cerucuk bambu.

Menurut Suroso, dkk. (2008) pemakaian cerucuk bambu pada lempung lunak dapat meningkatkan daya dukung. Kenaikan daya dukung dengan memakai cerucuk memberikan kontribusi yang cukup besar pada lempung lunak sekitar 2,2 kali daya dukung tanah tanpa dipasangi cerucuk.

Resmawan, dkk (2016) menambahkan campuran limbah karbit dan pasir pada tanah lempung maka nilai pengembangan tanah (swelling) menurun serta nilai CBR dan Konsolidasi tanah lempung semakin meningkat. Nilai pengembangan tanah pada kadar $0 \%, 5 \%, 10 \%$ dan $15 \%$ secara berurutan 1,9\%; 0,22\%; 0,19\%; dan 0,008 $\%$. Nilai CBRSoaked terbaik tanah terdapat pada campuran $5 \%$ dengan nilai penetrasi 0,1 " dan 0,2 " adalah 9,08 dan 6,32. Nilai CBR Unsoaked terbaik tanah terdapat pada campuran $15 \%$ dengan nilai penetrasi 0,1 " dan 0,2 " adalah 15,26 dan 12,59 . Sedangkan nilai Indeks Pemampatan (Cc) terkecil pada kadar campuran $15 \%$ yaitu 0,133 dan tertinggi pada kadar $5 \%$ yaitu 0,45 . Nilai Koefisien Pengembangan (Cr) terkecil terdapat pada campuran $10 \%$ yaitu 0,11 dan terbesar $0 \%$ yaitu 0,036 . Nilai Koefisien Konsolidasi (Cv) terbesar pada campuran 0 $\%$ yaitu $0,42 \mathrm{~cm}^{2} /$ menit dan terkecil $15 \%$ yaitu $0,02 \mathrm{~cm}^{2} /$ menit.

Menurut Ludfian, dkk (2017) menyatakan bahwa abu sekam padi dan pasir sebagai bahan campuran tanah lempung dapat meningkatkan daya dukung tanah, memperkecil penurunan lapisan tanah dan potensi pengembangan tanah.nilai Swelling tanah asli yaitu 1,93\%, kemudian pada tanah dengan campuran $2 \%$ abu sekam padi $+20 \%$ pasir yaitu $0,67 \%$. Hasil uji CBR tanah asli yaitu $17,82 \%$, nilai CBR maksimal terjadi pada tanah dengan campuran $2 \%$ abu sekam padi $+20 \%$ pasir yaitu $26,06 \%$. Dari uji Konsolidasi menghasilkan nilai $\mathrm{Cc}, \mathrm{Cr}$ dan $\mathrm{Cv}$ terbesar pada tanah kondisi asli. Sedangkan nilai $\mathrm{Cc}, \mathrm{Cr}$ dan $\mathrm{Cv}$ terkecil terjadi pada tanah dengan campuran $2 \%$ abu sekam padi $+20 \%$ pasir. Nilai Cc dari 0,2109 menjadi 0,1028; nilai $\mathrm{Cr}$ dari 0,0299 menjadi 0,0121; kemudian untuk nilai Cv dari 10,1993 $\mathrm{cm}^{2} /$ menit menjadi $1,8032 \mathrm{~cm}^{2} /$ menit. 
Mineral lempung merupakan suatu golongan butir tertentu yang menghasilkan sifat khusus pada tanah yang mengandung mineral lempung. Jenis mineral lempung yang paling terkenal adalah kaolinite, illite, dan montmorillonite. Struktur mineral ini disebut kristalin, yaitu molekulnya tersusun sehingga merupakan "kesatuan" dengan bentuk tertentu (seperti lapisan). Ada dua kesatuan khusus, yaitu "silica tetrahedron" dan "alumina octahedron". Kesatuan ini tersusun sehingga merupakan butir sangat kecil dengan bentuk seperti piring plate-like. (Wesley, 2012).

Menurut (Utami, 2016) Stabilisasi tanah adalah suatu cara yang digunakan untuk mengubah atau memperbaiki sifat tanah dasar sehingga diharapkan tanah dasar tersebut mutunya dapat lebih baik dan dapat meningkatkan kemampuan daya dukung tanah dasar terhadap konstruksi yang akan dibangun diatasnya.

Istilah penurunan menunjukkan amblesnya suatu bangunan akibat kompresi dan deformasi lapisan tanah di bawah bangunan. Penurunan settlement akan terjadi jika suatu lapisan tanah mengalami pembebanan. Penurunan juga dipengaruhi oleh sebaran tanah lunak atau lempung yang terdapat di bawah permukaan pada dataran aluvial. Penurunan akibat beban adalah jumlah total penurunan segera immediate settlement dan penurunan konsolidasi consolidation settlement (Hermansyah, 2018).

Oleh sebab itu, akan kami lakukan penelitian perkuatan pada tanah lempung jenuh air menggunakan metode penambahan bahan pasir dan trucuk bambu. Adapun tujuan penelitian ini adalah untuk mengetahui klasifikasi jenis tanah, properti tanah pengujian, dan pengaruh penggunaan metode penambahan variasi perkuatan tanah lempung jenuh air dengan menggunakan pasir dan cerucuk bambu, terhadap penurunan tanah lempung, kadar air, dan analisis T90, Tanah lempung yang dibuat jenuh air yang berasal dari Dusun Kalangan, Desa Bangunjiwo, Kecamatan Kasihan, Kabupaten Bantul, Daerah Istimewa Yogyakarta

\section{METODE}

Kajian ini menggunakan metode eksperimen di laboratorium menggunakan model. Pelaksanaan eksperimen pengujian dilakukan di Laboraturium Mekanika Tanah, Jurusan Pendidikan Teknik Sipil dan Perencanaan, Fakultas Teknik, Universitas Negeri Yogyakarta (JPTSP FT UNY). Pengujian ini dilaksanakan dengan menguji tanah di laboratorium untuk mendapatkan properti tanah sebagai berikut:

\begin{tabular}{cl} 
Tabel 1. Jenis pemeriksaan properti tanah \\
\hline No. & \multicolumn{1}{c}{ Jenis Pemeriksaan } \\
\hline 1 & Kadar Air \\
2 & Berat Jenis \\
3 & Batas Cair \\
4 & Batas Plastis \\
5 & Indek Plastisitas \\
6 & Batas Susut \\
7 & Kuat Tekan Bebas \\
8 & Berat Volume Kering Optimum \\
9 & Kadar Air Optimum \\
10 & Kohesi \\
11 & Koefisien Pemampatan \\
12 & Koefisien Pengembangan \\
13 & CBR Laboratorium \\
\hline
\end{tabular}

Kajian tanah ini menggunakan beberapa alat dan bahan untuk proses pengujian. Adapun bahan-bahan yang digunakan dalam pengujian ini adalah sebagai berikut:

1. Tanah Lempung Tanah lempung pada pengujian ini diambil dari Dusun Kalangan, Desa Bangunjiwo, Kecamatan Kasihan, Kabupaten Bantul, Daerah Istimewa Yogyakarta. Tanah dipecah-pecah kemudian di saring lolos saringan No. 4 dan pada saat pengujian tanah dibuat jenuh air dengan cara tanah di rendam disdalam air di dalam box baja benda uji selama $1 \times 24$ jam.

2. Air

Air yang digunakan pada penelitian ini merupakan air tanah yang besih yang 
Pengaruh Penggunaan... (Dian/hal. 64-73)

berasal dari Laboraturium Mekanika Tanah, Fakultas Teknik, Universitas Negeri Yogyakarta. Air ini digunakan untuk membuat kondisi tanah menjadi jenuh air.

3. Pasir

Pasir yang digunakan adalah pasir alami dan lolos saringan No.4.

4. Tusuk Sate

Pada penelitian ini tusuk sate digunakan sebagai pengganti atau permodelan dari cerucuk bambu. Tusuk sate yang dipakai berdiameter $\pm 2 \mathrm{~mm}$ dengan panjang 10 $\mathrm{cm}$.

Guna memperlancar jalannya penelitian ini, maka diperlukan beberapa alat-alat penujang. Adapun alat-alat tersebut antara lain:

1. Boks baja

Boks ini merupakan alat utama yang digunakan dalam penelitian ini sebagai tempat menaruh tanah lempung. Boks ini berukuran panjang $100 \mathrm{~cm}$, lebar $100 \mathrm{~cm}$ dan tinggi $40 \mathrm{~cm}$ terbuat dari plat baja setebal $4 \mathrm{~mm}$. Besi Pemodelan Embankment

Pemodelan

Embankment menggunakan pelat besi yang berbentuk trapesium dengan ukuran $20 \mathrm{~cm} \times 20 \mathrm{~cm}$ pada bagian alas dan $10 \mathrm{~cm} \times 10 \mathrm{~cm}$ pada bagian atas dengan ketinggian sebesar 10 $\mathrm{cm}$.

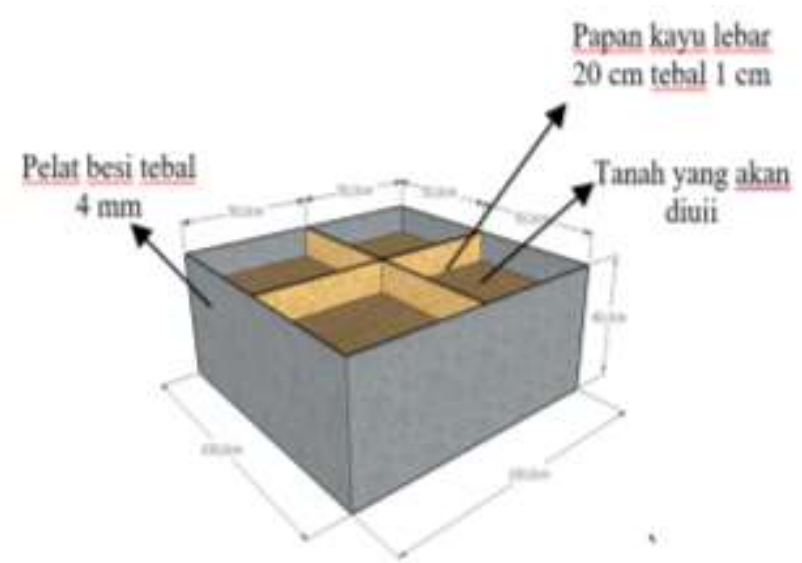

'Gambar 1. Boks baja

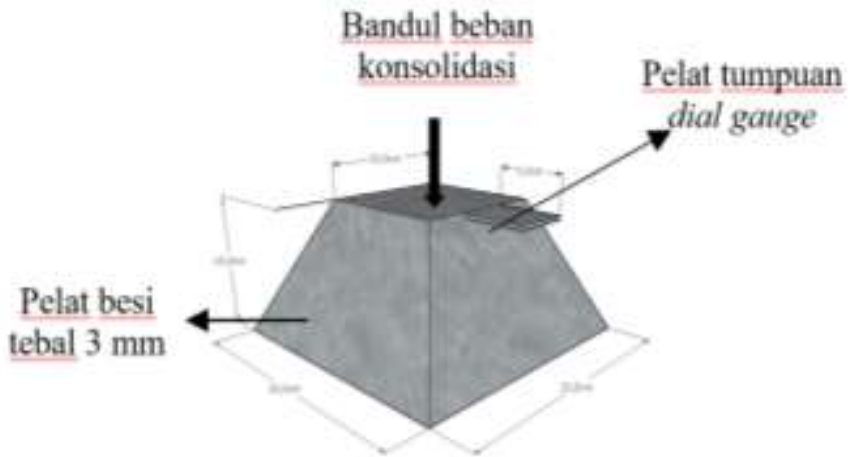

Gambar 2. Besi pemodelan embankment

2. Alat penunjang pengujian penurunan tanah

a. Bandul Beban Konsolidasi

b. Dial Gauge

c. Stopwatch

d. Penggaris

e. Pipa Alumunium

f. Cawan

g. Timbangan Digital

h. Papan Kayu

Tahapan pelaksanaan pengujian ini dilakukan dimulai dengan pengujian properti tanah yang berasal dari Dusun Kalangan, Desa Bangunjiwo, Kecamatan Kasihan, Kabupaten Bantul, Daerah Istimewa Yogyakarta. Kemudian dibuat pemodelan dengan cara tanah dimasukkan ke dalam box baja berukuran panjang $100 \mathrm{~cm}$, lebar $100 \mathrm{~cm}$ dan tinggi $40 \mathrm{~cm}$ terbuat dari plat besi setebal 4 $\mathrm{mm}$.

Jumlah sampel pengujian yaitu terdiri atas tanah tanpa perlakuan (TTD), Tanah dengan perlakuan Kolom pasir vertical (TPV), Tanah dengan perlakuan Layer pasir (TPH), Gabungan TPV dan TPH (CTPVH) dan tanah dengan perlakuan Trucuk bambu (TCB). Masing-masing perlakuan diuji dengan cara pembebanan secara bertahap dengan pemberian pembebanan/tekanan berturutturut sebesar $0.0125 \mathrm{~kg} / \mathrm{cm}^{2}, 0.025 \mathrm{~kg} / \mathrm{cm}^{2}$, $0.05 \mathrm{~kg} / \mathrm{cm}^{2}$, dan $0.1 \mathrm{~kg} / \mathrm{cm}^{2}$. Untuk setiap tahapan pembebanan diamati selama 24 jam dimana pengamatan dilakukan seperi proses pengamatan pada pengujian konsolidasi tanah. Tahapan pengujian ini dapat dijelaskan pada diagram alir sebagai berikut seperti tergambar pada Gambar 4. 


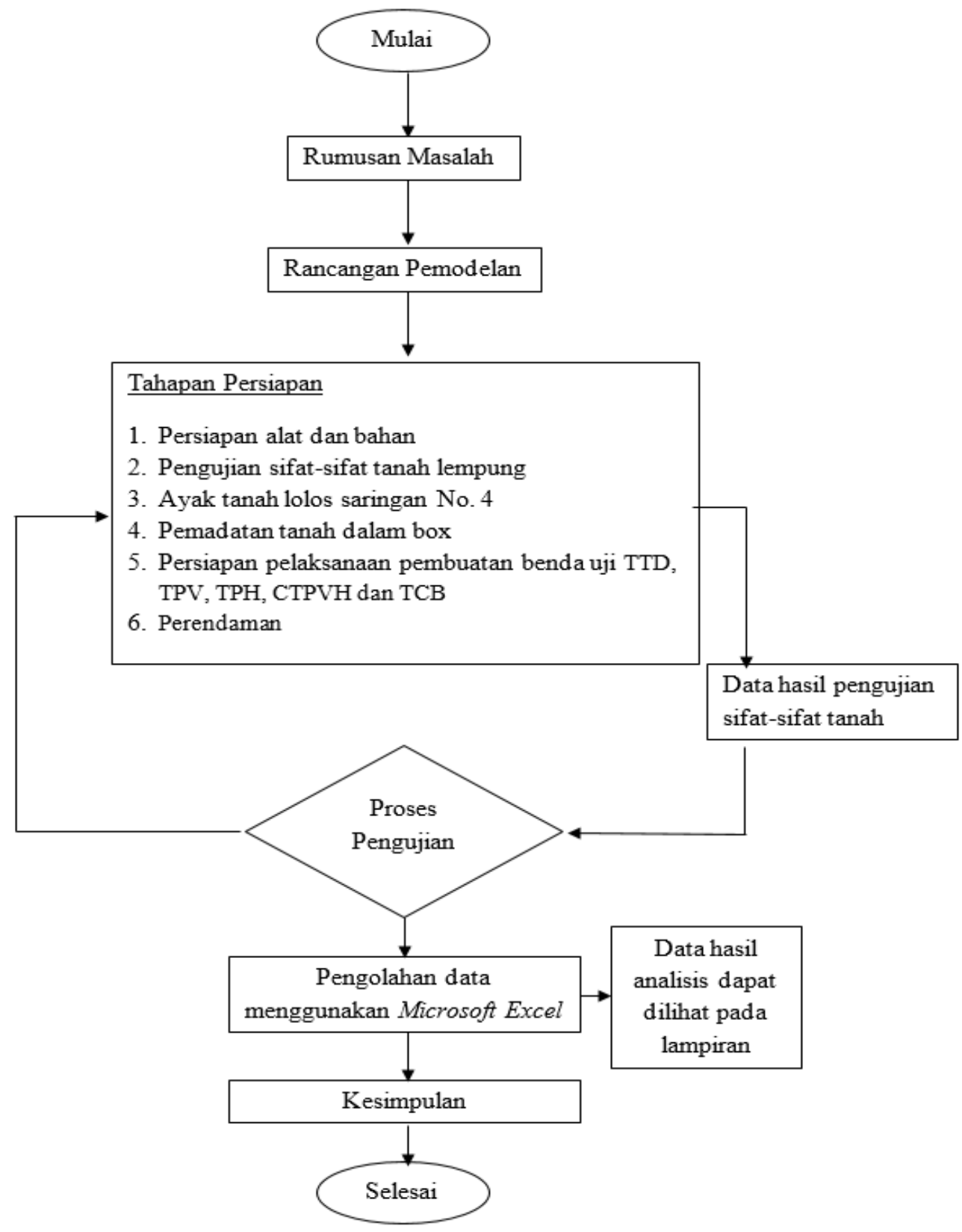

Gambar 4. Diagram alir tahapan pengujian

Langkah Pengujian tanah Lempung

1. Pengujian Penurunan Tanah

Ada 5 variasi pemodelan yang dibuat, yaitu tanah tanpa perlakuan (TTD), Tanah dengan perlakuan Kolom pasir vertical (TPV), Tanah dengan perlakuan Layer pasir (TPH), Gabungan TPV dan TPH (CTPVH) dan tanah dengan perlakuan cerucuk bambu (TCB). Diameter kolom pasir vertical drains adalah $1 \mathrm{~cm}$ dan jarak antar kolom pasir adalah $6.7 \mathrm{~cm}$. Tebal layer pasir horizontal adalah $1 \mathrm{~cm}$ dengan 2 lapis dan jarak antar lapisan adalah $9 \mathrm{~cm}$. Selanjutnya tanah dalam boks baja diberi air sampai tanah terendam dalam air selama 24 jam untuk membuat tanah menjadi jenuh air. Masing-masing variasi diamati penurunannya pada setiap penambahan beban $0.0125 \mathrm{~kg} / \mathrm{cm}^{2}, 0.025$ $\mathrm{kg} / \mathrm{cm}^{2}, 0.05 \mathrm{~kg} / \mathrm{cm}^{2}$, dan $0.1 \mathrm{~kg} / \mathrm{cm}^{2}$. Setiap pembebanan diamati selama 1444 menit atau 24 jam dengan pencatatan waktu disamakan dengan pencatatan waktu pengujian konsolidasi. 
Pengaruh Penggunaan... (Dian/hal. 64-73)

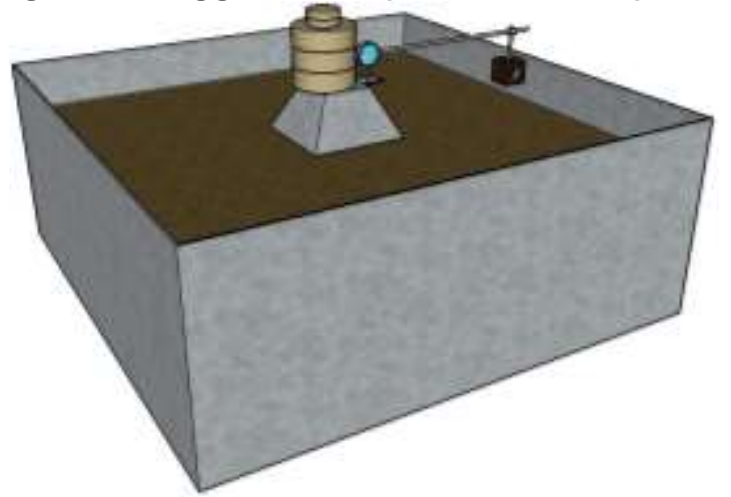

Gambar 3a. Setting up 3D pengujian

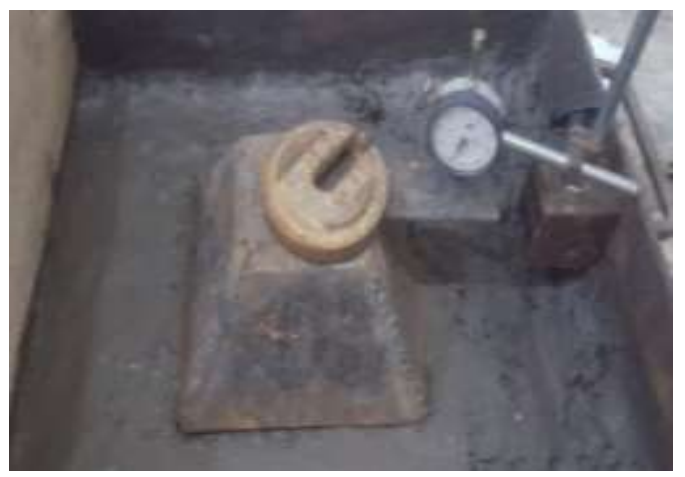

Gambar 3b. Foto Setting up 3D pengujian di laboratorium

2. Pengujian kadar air

Setelah pengujian pembebanan selesai dilaksanakan, langkah selanjutnya adalah pengambilan sampel tanah pada kedalaman $10 \mathrm{~cm}$ dan $20 \mathrm{~cm}$ untuk diuji kadar air.

\section{HASIL DAN PEMBAHASAN}

Berdasarkan yang berasal dari Dusun Kalangan, Desa Bangunjiwo, Kecamatan Kasihan, Kabupaten Bantul, Daerah Istimewa Yogyakarta kemudian diuji nilai sifat-sifat mekanis/properti tanahnya.

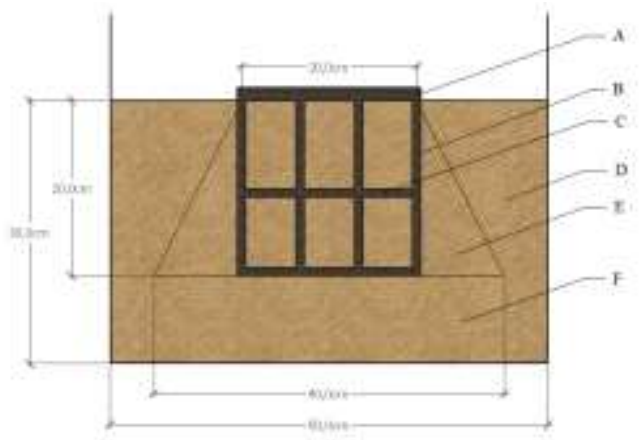

Gambar 4. Potongan melintang CTPVH

Keterangan

$A=$ Lapisan pasir permukaan

$B=$ Vertical drains kolom pasir

$\mathrm{C}=$ Horizontal drains layer pasir

$\mathrm{D}=$ Tanah dalam boks uji yang tidak terpengaruh sebaran tekanan beban $2 \mathrm{~V}: 1 \mathrm{H}$

$\mathrm{E}=$ Perkiraan tanah yang terkena sebaran tekanan beban $2 \mathrm{~V}: 1 \mathrm{H}$

$\mathrm{F}=$ Tanah dalam boks uji

Dimana hal itu untuk mengetahui kondisi tanah pasca pembebanan bagian permukaan dan bagian dalam dari tanah lempung.

Adapun hasil pengujian properti tanah yang dilaksanakan di Laboratorium Mekanika Tanah, JPTSP, FT, UNY didapatkan hasil sebagai berikut:

\begin{tabular}{ccc}
\multicolumn{3}{c}{ Tabel 2. Hasil Pemeriksaan properti tanah } \\
\hline No. & Jenis Pemeriksaan & Hasil \\
\hline 1 & Kadar Air & $46.85 \%$ \\
2 & Berat Jenis & 2.63 \\
3 & Batas Cair & 75.57 \\
4 & Batas Plastis & 29.76 \\
5 & Indek Plastisitas & 45.81 \\
6 & Batas Susut & 19.06 \\
7 & USCS & $\mathrm{CH}$ \\
8 & AASTHO & $\mathrm{A}-7-6$ \\
9 & Kadar Air Optimum & $39.2 \%$ \\
10 & Kohesi & $0.75 \mathrm{~kg} / \mathrm{cm}^{2}$ \\
11 & Koefisien Pemampatan & 0.234 \\
12 & Koefisien Pengembangan & 0.108 \\
13 & CBR Laboratorium & $6.594 \%$ \\
\hline
\end{tabular}


Pengamatan pengujian penurunan tanah dilakukan menggunakan dial gauge. Pencatatan waktu penurunan disamakan dengan pencatatan waktu konsolidasi laboratorium, selain itu beban/tekanan yang digunakan yaitu $0.0125 \mathrm{~kg} / \mathrm{cm}^{2}, \quad 0.025$ $\mathrm{kg} / \mathrm{cm}^{2}, \quad 0.05 \mathrm{~kg} / \mathrm{cm}^{2}$, dan $0.01 \mathrm{~kg} / \mathrm{cm}^{2}$. Adapun hasil pengamatan penurunan adalah sebagai berikut:

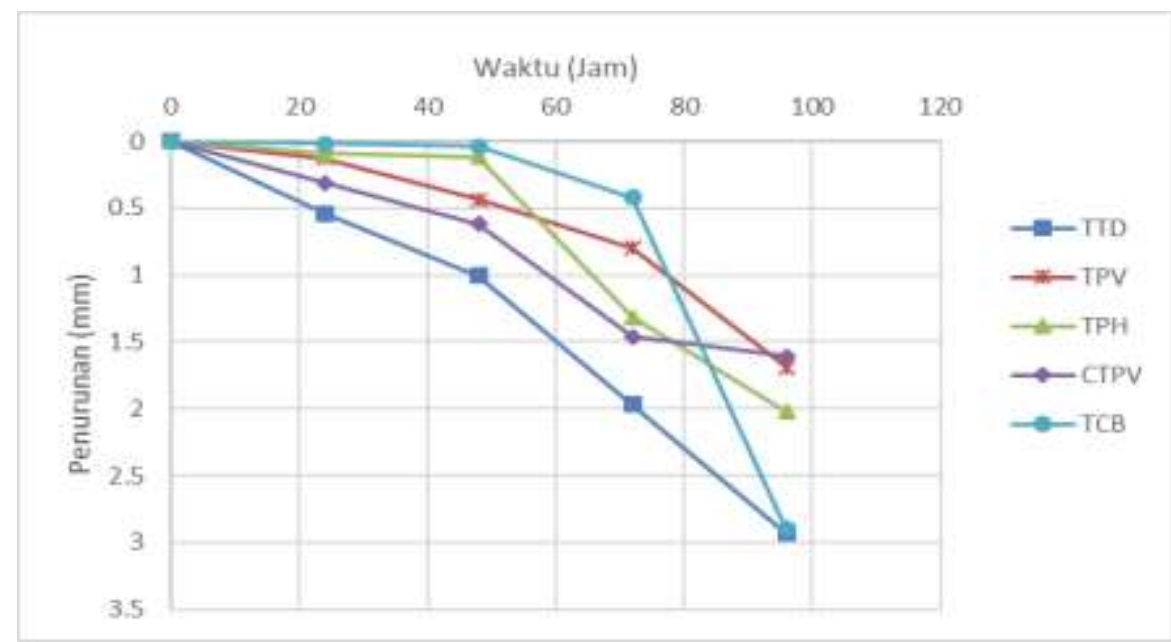

Gambar 5. Grafik penurunan tanah akibat pembebanan selama 96 Jam

Berdasarkan grafik pada Gambar 5, Penurunan maksimal yang terjadi pada TTD atau tanah asli dengan tekanan sebesar $0.1 \mathrm{~kg} / \mathrm{cm}^{2}$, adalah $2.93 \mathrm{~kg} / \mathrm{cm}^{2}$. Perilaku penurunan pada TTD Nampak menunjukkan trend penurunan yang tinggi pada masing-masing pemberian pembebanan/tekanan pada $0.0125 \mathrm{~kg} / \mathrm{cm}^{2}$, $0.025 \mathrm{~kg} / \mathrm{cm}^{2}, 0.05 \mathrm{~kg} / \mathrm{cm}^{2}$, dan $0.01 \mathrm{~kg} / \mathrm{cm}^{2}$, daripada pengujian yang lain. Adapun nilainya yaitu berturut-turut: $0,54 \mathrm{~mm} ; 1,005 \mathrm{~mm} ; 1,97$ $\mathrm{mm}$; dan 2,93 $\mathrm{mm}$. Akan tetapi setelah tanah lempung diberikan perlakuan penambahan perkuatan, nampak efektif untuk memperkecil laju penurunan pada tanah akibat beban yang ada.

Gambar 5 menunjukkan bahwa penambahan perlakuan TPV sangat efektif memperkecil penurunan. Pada pemberian tekanan 0.0125 $\mathrm{kg} / \mathrm{cm}^{2}, 0.025 \mathrm{~kg} / \mathrm{cm}^{2}, 0.05 \mathrm{~kg} / \mathrm{cm}^{2}$, dan 0.01 $\mathrm{kg} / \mathrm{cm}^{2}$ berturut-turut terjadi penurunan: 0,13 $\mathrm{mm} ; 0,439 \mathrm{~mm} ; 0,799 \mathrm{~mm}$ dan $1,69 \mathrm{~mm}$, atau memperkecil penurunan berturut-turut: $75,93 \%$; 56,32\%; 59,44\% dan 42,32\%. Penambahan TPV dinilai efektif karena pasir mempunyai sifat apabila terkena air langsung bisa memadat dan tidak mengalami kembang susut serta kolom pasir juga ikut menahan dan menyalurkan/menyebarkan beban/ tekanan kedalam tanah.

Setelah pengujian pembebanan selesai dilaksanakan, dilakukan pengambilan sampel kadar air tanah. Penambilan sampel pengujian kadar air diambil pada kedalaman $-10 \mathrm{~cm}$ dan $20 \mathrm{~cm}$. Pengujian kadar air pada kedalaman tersebut berfungsi untuk mengetahui besar pengurangan kadar air tanah setelah dilakukan pembebanan, dimana tanah lempung dalam kondisi jenuh air. Berikut ini Gambar 6 adalah Grafik hasil yang didapatkan dari pengujian kadar air. 


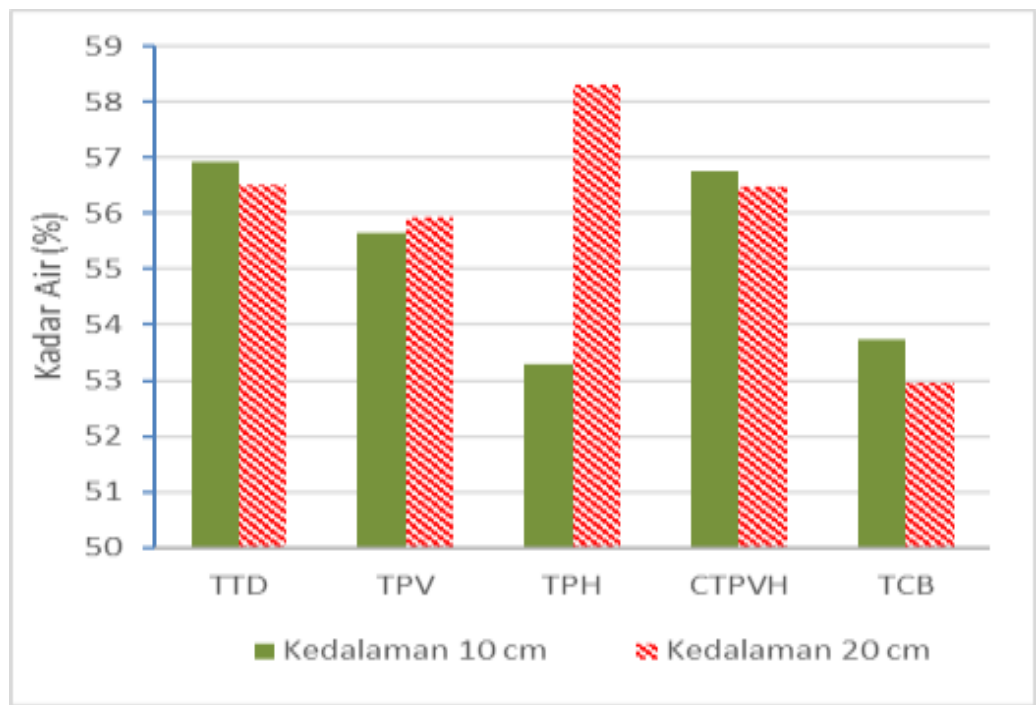

Gambar 6. Diagram kadar air setelah pembebanan

Berdasarkan diagram pada Gambar 6, dapat diketahui bahwa pada kedalaman $-10 \mathrm{~cm}$ penggunaan variasi TPH paling efektif dalam mengurangi kadar air dalam tanah lempung dengan kadar air tanah sebesar 53,30\% hal ini berarti mengurangi kadar air sebesar 3,62\% dari TTD, sedangkan untuk penggunaan CTPVH kurang begitu efektif mengurangi kadar air yaitu berkurang $0,16 \%$ dari kondisi tanah asli TTD yaitu dengan kadar air sebesar 56,92\%. Sedangkan pada kedalaman $20 \mathrm{~cm}$, penggunaan TCB lebih efektif dalam mengurangi kadar air. Adapun nilai kadar air pada penggunaan TCB adalah $52,97 \%$ berarti dapat mengurangi sebesar 3,55\% dari kadar air tanah lempung asli sebesar 56,62\%. Hal tersebut dikarenakan tekanan beban pada penggunaan TPH hanya terjadi di permukaan sehingga air yang terkandung didalam tanah lempung di daerah permukaan drainasi. Pada kedalaman -20 cmpenggunaan TCB lebih efektif hal ini diakibatkan karena beban yang terjadi dipermukaan langsung diterima oleh terucuk bambu dan disalurkan ke dalam sampai keujung terucuk bamboo, sehingga bagian ujung terucuk bambu terjadi tegangan ujung.

Dalam proses pengujian pembebanan, pengambilan data menggunakan konsep pengujian konsolidasi sehingga data yang diperoleh berupa grafik akar waktu dan penurunan. Dari grafik akar waktu dan penurunan tersebut akan didapatkan t90 yang memiliki arti waktu yang diperlukan dalam mencapai derajat konsolidasi 90\%. 


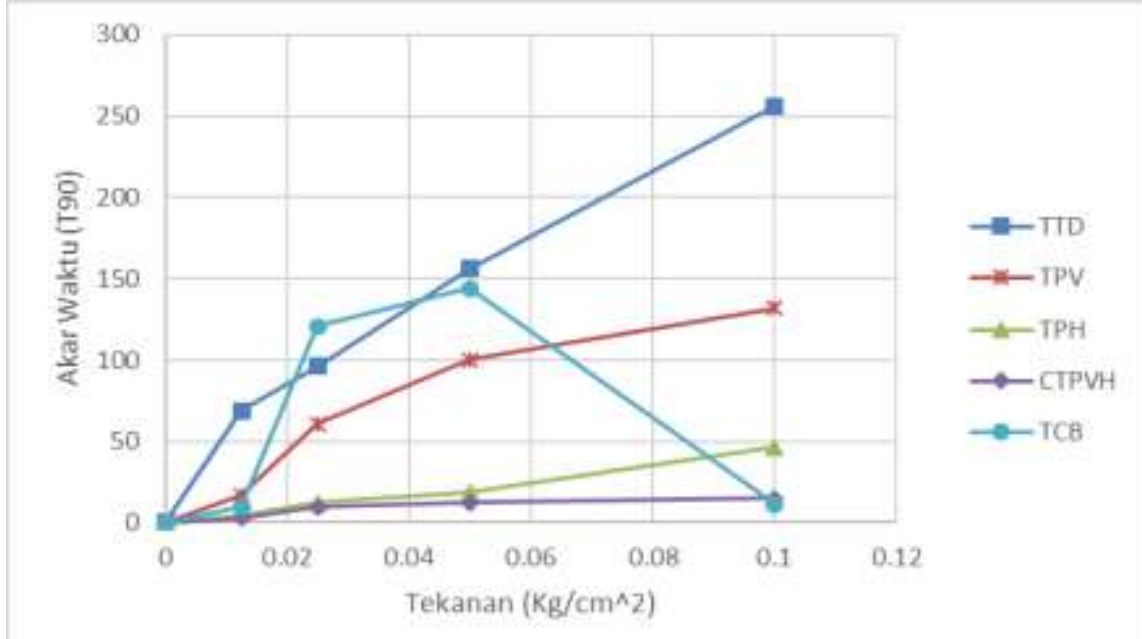

Gambar 7. Grafik waktu masing-masing tanah untuk mencapai t90

Berdasarkan grafik pada Gambar 7, penurunan tanah terhadap akar waktu menunjukkan bahwa perlakuan CTPVH pada beban $0,1 \mathrm{~kg} / \mathrm{cm}^{2}$ memiliki keefektifitas tinggi dalam proses konsolidasi yaitu sebesar $94,10 \%$ atau mempunyai waktu selisih t90 sebesar 240,79 menit dari tanah asli (TTD) dimana mempunyai nilai sebesar 256 menit atau dengan kata lain nilai t90 untuk CTPVH yaitu sebesar 15,21 menit. Efektifitas pada penambahan perlakuan CTPVH sudah ditunjukkan dari awal pengujian yaitu pada saat tanah dibebani sebesar $0.0125 \mathrm{~kg} / \mathrm{cm}^{2}$ pada hari pertama, $0.025 \mathrm{~kg} / \mathrm{cm}^{2}$ pada hari ke-dua, $0.05 \mathrm{~kg} / \mathrm{cm}^{2}$ pada hari ke-tiga, dan 0.1 $\mathrm{kg} / \mathrm{cm}^{2}$ pada hari ke-empat.

Pada penambahan perlakuan tanah lempung dngan menggunakan trucuk bamboo (TCB) terlihat bahwa sangat tidak efektif dalam proses konsolidasi untuk memangkas waktu t90 dikarenakan terjadi sangat lama yaitu sebesar 144 menit atau hanya $7,84 \%$ lebih cepat dibanding TTD pada tekanan $0.05 \mathrm{~kg} / \mathrm{cm}^{2}$. Akan tetapi pada tekanan $0.1 \mathrm{~kg} / \mathrm{cm}^{2}$ mengalami penurunan yang drastis dan dapat memangkas waktu sebesar 95,48\% dibanding TTD.

\section{SIMPULAN}

Berdasarkan hasil pengujian yang dilakukan menunjukkan bahwa: (1) Tanah lempung yang berasal dari Dusun Kalangan, Desa Bangunjiwo, Kecamatan Kasihan, Kabupaten Bantul, Daerah Istimewa Yogyakarta termasuk $\mathbf{C H}$ (clay high plastisity) menurut klasifikasi USCS dan A7-6 (40) menurut AASHTO (2) Properti tanah yaitu $\mathrm{G}=2,63, \quad \mathrm{LL}=74,71 \%$, $P L=29,76 \%, \quad I P=44,95 \%, \quad S L=19.06 \%$, $\mathrm{C}=0,75 \mathrm{~kg} / \mathrm{cm}^{2}$, kadar air optimum $=39,2 \%$.

(3) Penambahan perlakuan TPV sangat efektif memperkecil penurunan. Pada pemberian tekanan $0.0125 \mathrm{~kg} / \mathrm{cm}^{2}, 0.025$ $\mathrm{kg} / \mathrm{cm}^{2}, \quad 0.05 \mathrm{~kg} / \mathrm{cm}^{2}$, dan $0.01 \mathrm{~kg} / \mathrm{cm}^{2}$ berturut-turut terjadi penurunan: $0,13 \mathrm{~mm}$; 0,439 $\mathrm{mm} ; 0,799 \mathrm{~mm}$ dan $1,69 \mathrm{~mm}$, atau memperkecil penurunan berturut-turut: $75,93 \%$; $56,32 \% ; \quad 59,44 \%$ dan $42,32 \%$. Pada kedalaman $-10 \mathrm{~cm}$ penggunaan variasi TPH paling efektif dalam mengurangi kadar air dalam tanah lempung dengan kadar air tanah sebesar 53,30\% hal ini berarti mengurangi kadar air sebesar 3,62\% dari kondisi tanah asli TTD yaitu dengan kadar air sebesar 56,92\%. 
Sedangkan pada kedalaman $20 \mathrm{~cm}$, penggunaan TCB paling efektif dalam mengurangi kadar air yaitu 52,97\% berarti dapat mengurangi sebesar 3,55\% dari kadar air tanah lempung asli sebesar $56,62 \%$. Penambahan CTPVH pada beban $0,1 \mathrm{~kg} / \mathrm{cm}^{2}$ memiliki keefektifitas tinggi dalam proses konsolidasi yaitu sebesar $94,10 \%$ atau mempunyai waktu selisih T90 sebesar 240,79 menit dari tanah asli (TTD) dimana mempunyai nilai sebesar 256 menit atau dengan kata lain nilai T90 untuk CTPVH yaitu sebesar 15,21 menit.

\section{DAFTAR RUJUKAN}

Budi, G.S., 2011. Pengujian Tanah di Laboratorium Penjelasan dan Panduan. Yogyakarta: Graha ilmu.Risdianta, R.H., 2018. Perencanaan Perbaikan Tanah Lunak Menggunakan Preloading dengan Kombinasi Prefabricated Vertical Drain (PVD) dan Prefabricated Horizontal Drain (PHD) pada Pembangunan Kawasan Kota Summarecon Bandung Area Amanda dan Btari. Skripsi. Malang: Universitas Brawijaya.

Hardiyatmo, H.C., 2002. Mekanika Tanah I. Edisi. Ke-3. Yogyakarta: Gadjah Mada University Press.

Hermansyah, Didiek., 2018. Settlement (Penurunan) (Rangkaian dan pembahasan serta penjelasan tentang settlement). Makalah. Yogyakarta: Universitas Teknologi Yogyakarta.

Ludfian, M., \& Wibowo, D. E. (2017). Stabilisasi Tanah Lempung Menggunakan Campuran Limbah Abu Sekam Padi dan Pasir dengan Metode Pemadatan Laboratorium. EJournal Pend. Teknik Sipil Dan Perencanaan, 5(6), 19. Universitas Negeri Yogyakarta. Yogyakarta.

Resmawan, A., Wibowo, D. E., (2016). Pengaruh Campuran Pasir dan Limbah Karbit terhadap Parameter Penurunan Tanah Lempung menggunakan $U j i \quad C B R$ dan Konsolidasi dengan Pemadatan Laboratorium. E-Journal Pend. Teknik Sipil Dan Perencanaan, 4(5), 76. Universitas Negeri Yogyakarta. Yogyakarta.

Suroso, Harimurti dan Harsono, M., 2008. Alternatif Perkuatan Tanah Lempung Lunak (Soft Clay), Menggunakan Cerucuk dengan Variasi Panjang dan Diameter Cerucuk. Jurnal Rekayasa Sipil. Volume 2, No. $1-2008$ ISSN 1978 - 5658.

Utami, G.S., 2016. Stabilisasi Tanah Dasar (Subgrade) Jalan Darmahusada Indah Dengan Pasir Laut. Jurnal. Surabaya: Insitut Teknologi Adhi Tama.

Wesley, L.D., 2012. Mekanika Tanah untuk Tanah Endapan \& Residu. Yogyakarta: Andi. 